\title{
Küüditamispoliitika kui muistne tava Uus-Assüüria impeeriumis 9.-7. sajandini eKr ${ }^{1}$
}

\begin{abstract}
Vladimir Sazonov
Teesid: Assüüria kuningate poolt I eelkristlikul aastatuhandel sisseviidud küüditamispoliitika (akkadi keeles nasâhu) sai ulatuslikuks ja levinud nähtuseks I eelkristliku aastatuhande I poolel. Küüditati sadu tuhandeid inimesi erinevatest piirkondadest, et suruda maha nende mässuline meel ja tekitada hirmu. Sellel olid ka omad majanduslikud, poliitilised ja ideoloogilised, vahel koguni religioossed põhjused. Küüditatud rahvad tõid kaasa oma oskusi, ideid, jumalaid jne, samas viisid assüürlased oma "tehnoloogilisi saavutusi" vallutatud aladele. Seega leidis aset kultuuri, usundi ja tehnoloogia levitamine ja sünkretism. Assüürlaste poliitika oli ka pärast Assüüria impeeriumi kokkuvarisemist kasutusel Idamaade suurriikides Uus-Babüloonias, Pärsia impeeriumis jne. Muistses küüditamispoliitikas võib näha teatud analoogiat lähiajaloo kõige vägivaldsemate režiimidega - näiteks Stalini repressioonidega NSV Liidus või punaste khmeeridega Kambodžas jne.
\end{abstract}

Märksõnad: Assüüria, deporteerimine, nasâhu-poliitika, propagandistlikud tekstid, Sargon II, Sanherib ja Babülon, Tiglatpilesar III, varatotalitaarne ühiskond

\section{Sissejuhatus}

Küüditamine ehk deportatsioon - see sõna sunnib paljusid meist võpatama, eriti neid, kellel on mälestusi lähiajaloost - kasvõi Stalini jõhkrast valitsemisajast, mil paljude sugulased või inimesed ise olid sattunud nõukogude võimu kõikvõimsa repressiivmasina hammasrataste vahele.

Deporteerimine (ld deportatio - 'pagendamine, sundasumine'), on üks repressiivmeetmeid (ld repressio) - see on mõiste, mida tavaliselt seostatakse pigem lähiajalooga, tunduvalt harvem uus- ja keskajaga. Tegelikult on see inimkonna ajaloos väga muistne nähtus. 
Repressioonid, s.h massiküüditamised kui sellised on meile ajaloost ju hästi tuntud. Näiteks opritšnina Venemaal Ivan Julma valitsemisajal aastail 15641572, Prantsusmaal Pärtliöö veresaun ööl vastu 24. augustit 1572, Suure Prantsuse Revolutsiooni aegne terror (1793-1794), punane terror Nõukogude Venemaal 1918-1921, poliitilised repressioonid Venemaal 1920. ja 1930. aastatel, Stalini massilised repressioonid 1930. aastatest 1953. aastani, inimeste represseerimine Saksamaal Kolmandas Riigis (1933-1945), Hiina Rahvavabariigi kultuurirevolutsioon 1966-1969, punaste khmeeride võim Kambodžas, Idi Amin Dada diktatuur Ugandas 1970. aastatel jt olid nähtavasti ajaloo kõige tuntumad ja vägivaldsemad režiimid. J. Stalini korraldatud küüditamised Nõukogude Liidus alates 1930. aastatest kuni 1953. aastani on oma jõhkruse poolest mõnes mõttes võrreldavad koguni Assüürias ja Babüloonias rakendatud küüditamispoliitikaga, kuigi lähiajalooga selliste paralleelide tõmbamisel peab olema suhteliselt ettevaatlik. Teatud analoogia on siiski jälgitav.

Paljud diktatuurid harrastasid muuhulgas ka küüditamist, eriti paistsid sellel alal silma Nõukogude Liit ja Kolmas Riik. Mõiste deportatsioon võeti kasutusele suhteliselt hilja. See sai tähenduse alles Prantsusmaa kriminaalkoodeksis 18.-19. sajandil pagendamise eriliste liikide määratlemiseks. Samas esines küüditamist nähtusena mitte ainult lähiajaloos, uusajal või keskajal, vaid koguni vanal ajal muistses Roomas ja Kreekas, kuid ka muistses Lähis-Idas ja muidugi vanas Hiinas. Relegatio ja deportatio esinesid juba muistses Roomas ning tähendasid teatud hulga elanike vägivaldset ja sunduslikku ümberasustamist või riigist väljasaatmist. Näiteks Lucius Cornelius Sulla, saades 82. aastal eKr Rooma diktaatoriks, saatis Itaaliast hulgaliselt välja inimesi, kes ei tundunud talle usaldusväärsed, paljudest linnadest saadeti välja veteranid - sõjaväest vanaduse tõttu vabastatud sõdurid. 120000 veterani said maatüki ja kolisid Roomast ära (Durant 1995: 140). Alles diktaatoriks saades seadis Sulla sisse proskriptsioonid (mustad nimekirjad isikutest, kes tuli hukata) ning käskis tappa 40 senaatori ja 2600 ratsaniku seisuses roomlast (Durant 1995: 140). Väga paljud pagendati.

Küüditamisega on hiljem silma paistnud ka mitmed Rooma impeeriumi (aastad $28 \mathrm{eKr}-476 \mathrm{pKr}$ ) keisrid, kes pagendasid juute ja teisi rahvaid. Näiteks kui Rooma keisri Vespasianuse (valitses aastail 69-79 pKr) poeg väejuht Titus (keiser aastail 79-81 pKr) vallutas 70. aastal pKr mõni aasta varem ülestõusnud Jeruusalemma, olevat roomlased võtnud vangi 97000 inimest, kuid Jeruusalemma vallutamisel sai surma oletatavasti 1100000 inimest (Dieter \& Günther 1990: 239). 


\section{Küüditamine Mesopotaamias III aastatuhandel eKr, lühikene ülevaade}

Küüditamine kui selline leidis aset juba III eelkristlikul aastatuhandel ja selle kohta on säilinud allikaid. Samal ajal leidsid aset ka esimesed inimeste dokumenteeritud massilised mõrvamised, kuid see oli tollal veel üsna haruldane.

Esimeste rahvaste küüditajatena (kuid see polnud veel regulaarne poliitika) paistsid silma Akkadi kuningad, kes 24.-23. sajandil eKr lõid Mesopotaamias tugeva tsentraliseeritud impeeriumi tüüpi kuningriigi. Nende võimu alla sattusid nii Sumer, kui ka Akkad, Süüria, Põhja-Mesopotaamia alad ja osa Eelamist (Edela-Iraan). See oli muistses Mesopotaamias üleüldse esimene suurriiklik moodustis, katse luua esimene tsentraliseeritud impeeriumi tüüpi riik, eesotsas despootliku ja koguni jumalikustatud kuningaga nagu seda oli Narām-Su'en (2254-2218 eKr). Akkadi ehk Sargoni dünastia kuningad hakkasid oma võimu tugevdamiseks määrama linnadesse ja tähtsamatesse templitesse endale ustavaid inimesi - sugulasi ja kaaskondlasi (Sazonov 2008: 14-24). Kõik see ja ka muud jõhkrale Akkadi keskvõimu poliitikale omased meetmed tekitasid vallutatud aladel viha ja rahulolematust ning see viis tihti mässudeni, mida Akkadi kuningad (seni kuni Akkad oli veel piisavalt tugev ja mõjuvõimas) veriselt maha surusid. Eriti paistis jõhkrusega silma näiteks Akkadi impeeriumi rajaja Sargon I (2334-2279 eKr) pärija ja poeg kuningas Rimuš. Julmades arveteõiendustes, mida Rimuš korraldas, hävis arvatavasti märgatav osa muistsest Sumeri aadelkonnast. Kuid sellisel poliitikal oli ka oma eesmärk - tekitada hirmu kohaliku elanikkonna seas, et rahvas kardaks ega mässaks (IDV 1983: 243, 244).

On teada, et Rimuši valitsemise alguses umbes 2270. aastatel oli ülestõus terves Sumeris, impeeriumist lõid lahku Eelam ja muud alad. Kuid Rimuš tegutses kiirelt ja väga edukalt. Ta surus maha suure ülestõusu Sumeri linnades. Sellest kirjutas ta oma raidkirjades, kus ta lausa hooples ning tõi ära täpse ja hirmuäratava statistika. Toon siinkohal paar näidet Rimuši raidkirjas esinevatest statistilistest andmetest, mis võivad küll olla liialdatud, aga seda ei saa me tõestada.

Raidkiri Rīmuš E2.1.2.1, read 1-12:

Rimuš, maailma kuningas, oli võidukas Adabi ja Zabala [linnade] üle lahingus ja tappis 15718 meest. Ta tõi 14576 vangi (RIME 2, Rīmuš E2.1.2.1, lk 41, read 1-12). 
Tuleb mainida, et ükski Sumeri varadünastlikest valitsejatest (2800/2700-2334) ei nimetanud enne Akkadi impeeriumi esilekerkimist üheski oma raidkirjas nii suuri arve ning üleüldse polnud massimõrvamine ja küüditamine sumerlastele omane. Üheski Sargonite-eelse ehk varadünastilise ajajärgu raidkirjas ei esine küüditatute arvu ega isegi sündmuse mainimist. Vähemalt kirjalikud andmed selle kohta puuduvad. Muidugi tapeti lahingutes vastaseid ja võeti sõjavange, vangid muudeti tihtipeale orjadeks ja viidi oma riiki. Loomulikult ei tasu unustada, et Sumer, mis koosnes kümnetest linnriikidest, polnud tollal veel üks Akkadi impeeriumi valduses olevatest aladest, vaid oli iseseisev piirkond, koosnedes paarikümnest iseseisvast linnriigist, millest kõige mõjuvõimsamad oli Uruk, Ur, Umma, Lagaš, Kiš, Adab, Sippar jne.

Tulles tagasi Akkadi kuninga Rimuši juurde, peab märkima, et teiste Rimuši raidkirjade põhjal tundub asi veelgi jõhkram, sest Rimuši korraldatud terror, mis oli suunatud eriti Sumeri oligarhia vastu, jätkus tema valitsemise lõpuni. Näiteks raidkiri $R \bar{i} m u s ̌$ E2.1.2.2, read 1-17:

Rimuš, maailma kuningas, oli võidukas Umma ja KI.AN’i [linna] üle lahingus ja tappis 8900 meest. Ta võttis 3540 vangi. Seejärel vangistas ta En-x’i, Umma asehalduri ja Lugal-KA, KI.AN’i asehalduri.

Read 29-35:

Seejärel, saatis ta välja 3600 inimest nendest linnadest ja põrmustas need (RIME 2, Rīmuš E2.1.2.2, lk 43-44, read 1-17, 29-35).

Või siis raidkiri Rīmuš E2.1.2.3, read 1-36:

Rimuš, maailma kuningas, oli võidukas Uri ja Lagaši üle lahingus ja tappis 8040 meest. Ta võttis 5460 vangi. Seejärel võttis ta vangi Kaku, Uri kuninga, Kutuš-id'i, Lagaši asehalduri. Seejärel vallutas ta need kaks [linna] ja hävitas nende mõlema mü̈rid. Seejärel saatis ta välja 5985 meest nendest kahest linnast ja hävitas need [täielikult] (RIME 2, Rīmuš E2.1.2.3, lk 45-46, read 1-36).

Järgnevates Rimuši raidkirjades suurenevad tapetute ja vangistatute arvud veelgi. Nii on näiteks raidkirjas $R \bar{\imath} m u s ̌$ E2.1.2.4 esitatud arvud lausa rekordilised. Raidkiri Rìmuš E2.1.2.4, read 1-29:

Rimuš, maailma kuningas - jumal Enlil andis talle tõelise kuningavõimu. Tema [Rimuš] oli tervenisti kolm korda võidukas Sumeri üle lahingutes. Ta tappis 11322 meest. Ta võttis x vangi. Seejärel, võttis ta vangi Kaku, Uri kuninga ja tema asevalitsejad. 
Read 38-72:

Seejärel saatis ta välja 14100 meest Sumeri linnadest ja hävitas need. Seejärel vallutas ta nende linnad ja hävitas nende müürid. Seepeale, tõusis Kazallu tema tagasitulekul üles. Ta vallutas selle ja tappis Kazallu piiride vahel 12052 meest. Ta võttis 5862 vangi. Seejärel vangistas ta Ašaredi, Kazallu asehalduri ja hävitas selle [Kazallu] müürid. Kokku 54016 meest [kaasa arvatud] tapetud, vangid ja mehed, keda hävitati [---] sõjakäik (RIME 2, Rīmuš E2.1.2.4, lk 47-48, read 1-29, 38-72).

Rimuš, kes valitses Akkadis vaid seitse aastat, langes vandenõu ohvriks. Brutaalne despoot, kes oli tapnud kümneid tuhandeid inimesi (võib-olla isegi sadu) ja deporteerinud vähemalt sama palju, kartis, et tema kaaskondlased võivad korraldada talle atentaadi ning keelas neil siseneda enda juurde relvadega. Kuid ükskord tulid tema juurde õukondlased ja loopisid ta oma silinderpitsatitega surnuks. Vandenõu korraldas arvatavasti tema vend Maništušu (Jaritz 1964: 41; Oates 1979: 35).

Ka teised Akkadi kuningad Maništušu ja Narām-Su'en paistsid silma vägivalla poolest ning mainisid tapetuid ja küüditatuid, aga nende esitatud arvud raidkirjades polnud nii suured kui Rimušil, kuid siiski ligilähedased. Samas on teada, et Narām-Su'en hävitas täielikult Ebla linnriigi, purustas mitmed ülestõusnud Sumeri ja Eelami linnad ja muidugi tappis kümneid tuhandeid inimesi, ka deporteeritute arv oli üsna suur (Oates 1979: 36, vt ka teksti FAOS 7: 110-111).

Kui vaadelda tuhandet aastat pärast Rimuši valitsemisaega, näeme, et sel ajal on Mesopotaamias leidnud aset sõjad, massimõrvad, küüditamised, aga ükski neist ei lähene oma arvudelt Rimuši "saavutustele". Küüditajatena on mõnevõrra paistnud silma II eelkristlikul aastatuhandel Anatoolias ja PõhjaSüürias valitsenud hetiidi kuningad, kes on oma annaalides tihti hoobelnud, kui palju inimesi nad on tapnud ja kui palju kitsi röövinud. Alles Assüürias sai selline poliitika regulaarseks (vt ka Stadnikov 1998: 137-139).

\section{Kesk-Assüüria ajastu deporteerimise juhtumid}

Kuid tõeline jõhkrus leidis aset hiljem - 1000 aastat pärast Akkadi riigi kokkuvarisemist ning toimus mitte kusagil mujal kui Assüürias. Esimene kindel teade selle kohta, et Assüürias rakendati massimõrvamist ja küüditamist, pärineb 13. sajandist eKr, mil Kesk-Assüüria impeerium saavutas oma võimsuse tipu. Nimelt mainib Kesk-Assüüria kuningas ja suur vallutaja Salmanassar I 
(1275-1243 $)^{2}$ muude suurte tegude ja vallutuste seas ühes oma raidkirjas ka võitu liidus olnud hetiitide ja aramealaste üle: "Mina veristasin hetiitide ja aramealaste armeed ja nende liitlasi nagu lambaid." Veel hoopleb Salmanassar I samas raidkirjas, et hävitas 180 linna Süürias ning küüditas ja torkas pimedaks 14400 inimest, kes olid lahingus ellu jäänud (RIMA 1, Shalmaneser I A.0.77.1, lk 184, read 74-80). Muidugi deporteeriti need 14400 meest Assüüriasse Salmanassari käsul. Seega panid Salmanassar I ja tema järglased arvatavasti maailma ajaloos aluse massideporteerimisele.

Veelgi suurema brutaalsusega paistis silma Salmanassar I poeg kuningas Tukūltī-Ninūrta I (Klengel 1961: 67-77), kes pidas mitmeid veriseid sõdu hetiitide, hurriitide, Nairi rahvaste ja Eelamiga ning vallutas Babüloonia ${ }^{3}$. Ühest Tukūltī-Ninūrta I raidkirjast võib välja lugeda :

Minu valitsemise alguses [ja] minu troonil olemise alguses deporteerisin ma 28800 hetiidi sõjameest sealpoolse Eufrati jõe kaldalt [Süüriast] ning tõin nad oma kuningriiki. Ma vallutasin Paphu ja Uqumanu maad kuni Šarnida ja Mehru maadeni. Igal aastal saan ma regulaarselt andamit nendest maadest ja nende mägede vilju [---]. Ma lömastasin oma jalge [ees] olevad kuningad, nende juhid, ja rakendasin nende suhtes orjust. Oma ületamatu tugeva võimsusega ületasin ma korduvalt [sageli] võimsaid mägesid [ja] ääretult raskeid vahemaid, radasid, mida ükski teine kuningas ei teagi (RIMA 1, A.0.78.23, read 27-42).

Sõjakäigu tulemusena olevat Tukūltī-Ninūrta I deporteerinud 28800 hetiidi sõjameest. Huvitav, et see arv on täpselt kaks korda suurem kui tema isal! Mida ta tahtis sellega näidata? Et ta on kaks korda kangem mees kui ta isa? Pole teada. Kindlasti oli Tukūltī-Ninūrta I deporteerinud inimesi ka teistelt vallutatud aladelt, kasvõi Babülooniast, aga teavet selle kohta tema raidkirjades pole.

Juba tsiteeritud raidkirjas hoopleb Tukūltī-Ninūrta I:

Suurte jumalate, minu isandate, jumalate Aššuri, Enlili ja Šamaši toetusel ning jumalanna Ištari abiga, taeva ja allilma prouaga, kes marsib minu armee ees, lähenesin mina Kaštiliašile, Karduniaši [Babüloonia] kuningale, et pidada lahingut [temaga]. Ma võitsin tema armee ja tapsin ta sõjamehi. Keset lahingut ma vangistasin Kaštiliaši, kassiitide kuninga [---] (RIMA 1, A.0.78.23, read 56-65).

Pärast Tukūltī-Ninūrta I surma (ca 1206 eKr) käis Assüüria alla, aga sada aastat hiljem suutis selle lühikeseks ajaks taastada Tiglatpileser I, kes on samuti 
rahvaid deporteerinud (Tiglatpileser I kohta vt Olmstead 1917: 169-185; Llop Raduá 2003: 204-210).

\section{Uus-Assüüria kuningad - tõelised küüditajad}

Selline küüditamine, mis leidis aset juba Kesk-Assüüria impeeriumi ajal 13. sajandil eKr, muutus varatotalitaarses Uus-Assüüria impeeriumis (883-612 eKr) regulaarseks ja vägagi levinuks (Oded 1979: 19). Salmanassar I ja TukūltīNinūrta I ning ka Tiglatpileser I (1115-1077) korraldatud deporteerimine ja massimõrvamine polnud veel laiahaardelised, regulaarsed ja levinud nähtused, vaid pigem stiihilised. Kuid 9.-7. eelkristliku sajandi Uus-Assüüria impeeriumis muutus see peagi üsna regulaarseks poliitiliseks meetmeks. Selleks ajaks oli see jõhker sissejuhatus järgmistele assüürlaste korraldatud veresaunadele Lähis-Idas ning terrori ja deporteerimispoliitikale, mis muutus Assüüria impeeriumi elanikkonna hirmutamisel ja ka hävitamisel tavapäraseks.

Näiteks Uus-Assüüria ajastu üks julmimaid valitsejaid, selle võimsuse ja hiilguse taastaja oli andekas väepealik ja äärmiselt militaristlik kuningas Tiglatpileser III (745-728 eKr), kes paistis silma suure vallutajana ja reformaatorina, samuti nasâhu- ehk küüditamispoliitika ühe tähtsaima rakendajana. Tema ajal muutusidki küüditamine ja massimõrvamine assüürlaste ametlikuks riiklikuks poliitikaks. Ainuüksi vallutatud aladelt, mis kuulusid võimsale Urartu kuningriigile, küüditas ta vähemalt 72950 inimest, seda mainib üks tema annaalidest (Tadmor 1994: 52; Ann. 17, tahvlid XIII-XIV, rida 9'). Lahingutes tapetud sõjameeste ja muul viisil tapetud Urartu elanike arvu see raidkiri ei maini, kuid tapmisest on juttu peaaegu kogu aeg. Kahjuks on see raidkiri fragmentaarne. Seega pole küüditatud ja tapetud urartulaste tegelik hulk teada. Urartu kuningas, kelleks oli tollal Sarduri, olevat kuningas Tiglatpileser III enda sõnul lasknud jalga nii kiiresti kui võimalik: "Selleks, et päästa oma elu põgenes Sarduri öösel, enne päikesetõusu lasi ta kiiresti jalga" (Tadmor 1994: 52, Ann. 17, tahvlid XIII-XIV, rida 10').

Pole ime, et Sarduri nii käitus, teades Tiglatpileseri jõhkrust. Just rida enne seda mainib Tiglatpileser III vähemalt 72950 Urartu inimese küüditamist (Tadmor 1994: 52, Ann. 17, tahvlid XIII-XIV, rida 9'). Ja veel enne seda ridades 6'-7' märgib Assüüria suurkuningas urartulaste tapmise kohta järgnevat:

[---] Ašš[uri], mu isanda, jõuga ja võimsusega, nendega ma võitlesin, [ja võitsin neid... ] nende [sõjamehi] ma tapsin [ja] täitsin mägede kuristikud [nende laipadega]. [Minu] sõjavankrid [---]. 
Selliste "vägitegudega" Tiglatpileser III muidugi ei piirdunud, vaid jätkas samas vaimus. Just temale omistatakse nasâhu-poliitika kasutuselevõtt (Beljavski 2001: 19, vt ka Sazonov 2006: 81).

Mida nasâhu-poliitika siis tähendas? Nasâhu põhimõte seisnes selles, et vallutatud rahvaste mässulise meele ohjeldamiseks, vastupanu mahasurumiseks ja hirmu tekitamiseks küüditati neid aeg-ajalt Assüüria kuningate käsul. Akkadi keeles tähendas nasâhu 'välja juurima, juurteni hävitama'. Kindlakäeliselt rakendatud nasâhu-poliitika, mida teostasid Assüüria kuningad alates Tiglatpileser III valitsemisajast, kandis algul küll vilja, sai aga lõpuks assüürlastele endile saatuslikuks. Asi seisnes selles, et kui muistsed assüürlased küüditasid vallutuste käigus kohalikke hõime ja rahvaid ning tõid nende asemele põlisassüürlasi Assüüria tuumaladelt, siis aastate ja sajandite jooksul assimileerus suurem osa Assüüria põlisrahvast kohalike elanikega ja assüürlased surid rahvusena välja (vt Beljavski 2001: 19-20; Sazonov 2006: 81). Tulles aga tagasi Tiglatpileser III juurde, kelle küüditamistest võiks kirjutada omaette suurema uurimuse, mainin veel põgusalt teist tema ülestähendust, kus on mainitud koguni 83000 inimese küüditamist (Tadmor 1994: 50, Ann. $19 *$, tahvlid XVI-XVIII, lk 62, rida 11). Toon näite veel ühest kroonikast (Ann. 6), mis on pärit Kalahi (Namrūdi) linnast:

1. [---] Hista, Harabisina, Barbaz’i, Tasa linna, Ulurusi jõge mööda üles, vallutasin ma ja võtsin 8650 inimest,

2. [---] 300 hobust, 600 eeslit, 1350 härga, 19000 lammast võtsin ma saagiks. Ma lammutasin, hävitasin ja põletasin tules.

3. [---] ja need linnad ma liitsin Assü̈̈riaga. Ma ehitasin linnad taas üles ja paigutasin sinna inimesed minu poolt vallutatud maadest.

4. [---] Aššuri, mu isanda, relvad seadsin üles sinna.

5. [---] Luqadanša, Quda, Elugia, Dania, Danziun, Ulay, Luqia, Abrania, (ja) Eusa

6. [---] ma võitsin. Ma tõin saagina kaasa 900 inimest, 150 härga, 1000 lammast, hobuseid, muulasid [ja] eesleid.

7. [---] nende linnu ma hävitasin ja laastasin, ja põletasin maha. Muqania inimesed nägid tolmupilve minu [vägede] marsist, ja Uri linn [---] (Tadmor 1994: 76, Ann. 5, lk 62, read 1-7).

Tiglatpileser III raidkirju on säilinud piisavalt palju ja neis toodud arvud on alati suured. Näiteks Sarrabanu vallutamise puhul mainib Tiglatpileser III 55000 inimese vangistamist (Tadmor 1994, Summ 7, Obverse, Late LIV, lk 160, rida 16), Dur-Balihaya linna vallutamisel võttis ta 40500 inimest koos 
nende varaga, jumalatega jne kaasa sõjasaagina (Tadmor 1994, Summ. 7, Obverse, Late LIV, lk 162, rida 21). Just Tiglatpileser III-ga algab Assüürias eriti verine ajajärk. Kõik tema järglased kuni Assüüria langemiseni 612. aastal eKr paistavad silma erilise vägivaldsusega - nad tapsid ja küüditasid sadu tuhandeid, koguni miljoneid inimesi. Näiteks pärast Iisraeli kuningriigi vallutamist umbes 721. aastal eKr deporteeris Assüüria kuningas Sargon II sealt 27280 juuti Mesopotaamiasse ja Meediasse. Sargon II küüditas inimesi veel korduvalt. Vallutatud Papa ja Lallukna linna elanikke küüditati tema käsul Damaskusesse. Vallutanud Harhari, millest sai ka Assüüria provints, küüditas ta Harhari elanikkonna tervenisti ja tõi sinna muust rahvusest asunikke, nähtavasti juute. Ka kõik vallutatud Gurgumi elanikud represseeriti, tapeti või deporteeriti.

Kuid rekordi püstitas Assüüria kuningas Sanherib ehk Sennaherib (704$680 \mathrm{eKr}$ ), kelle jõhkrus hämmastas isegi tema vägivaldseid järglasi. Tema kõige suurem tegu on muidugi Babüloni linna vallutamine ja totaalne hävitamine koos selle elanikega. Tollal oli Babülon maailma kõige suurem linn. Nii Sargon II kui ka tema järglased, eriti Sanherib olid Babüloni vallutamiseks võtnud ette mitu sõjaretke: aastail 702, 693, 691 ja 689 eKr (Brinkman 1984: 45-65). Kõikidele sõjaretkedele ja vallutustele järgnes Babülonis ülestõus ja linn vabanes taas Assüüria ikkest. Nii tuli Sanheribil linna korduvalt taasvallutada.

Sanherib võitis babüloonlaste liitlasi, tegi vallutusretke Lõuna-Eelami aladele ning vallutas ja hävitas lõpuks suures raevus täielikult Babüloni 689. aastal eKr.

Sanherib deporteeris sadu ja sadu tuhandeid babüloonlasi. Erinevatel hinnangutel võis Babülonis elada tollal ligikaudu 500000 inimest või isegi rohkem. Ta suutis peaaegu täielikult hävitada linna ja selle elanikkonna. Maad Babüloni ümber needis kuningas Sanherib 70 aastaks (Beljavski 2001: 31). Sanheribi tõttu said kannatada peaaegu kõik templid, muuhulgas Esagila tempel, mis oli Babüloonia peajumala Marduki peamine pühamu. Jumal Marduki kuju transporditi Babülonist Niinevesse (Brinkman 1984: 67-68). Niineve muutus Sanheribi ajal veelgi hiilgavamaks ja rikkamaks ning oli üks tolle aja suuremaid ja atraktiivsemaid linnu. Seega deporteeris Sanherib ka peajumal Marduki kuju Assüüriasse (Porter 2003: 51). Üks kroonika väidab:

\section{Sanheribi 8 [valitsemis] aastat}

Asarhaddoni 12 [valitsemis] aastat

[Kokku] 20 aastat - a [sus] Bel ${ }^{4}$ [Marduk] Baltilis [Aššuris]

4.ja akitu-pidustusi ${ }^{5}$ ei peetud (vt originaali Grayson 1975: 131). 
See tähendab, et uue aasta pidustusi Babülonis enam ei korraldatud. Isegi kui oleks lubatud seda teha, vaevalt oleks leitud kedagi elavat, kes neid korraldanuks. Linn, mis oli suurem kui Tallinn, oli muutunud põrmuks.

Babüloonia sõjakäiku kirjeldab Sanherib ühes oma kroonikas väga detailselt. Toon sellest vaid meid huvitavad lõigud:

read 9-10:

Minu isanda Aššuri jõuga ma piirasin sisse Kaldu maa [Babüloonia] 89 võimsat linna [ja] kindlust ja 620 väikest maakohta [küla] nende ümbruses, vallutasin ja rüüstasin. Urbi, Aramu ja Kaldu inimesi Urukis, Nippuris, Kišis, Hursagkalammas, Kuthas [ja] Sipparis ühes koos linnakodanikega, kes ennast tabada ei lasknud, viisin ma minema ja arvestasin saagi hulka (TUAT 2005, kd 2, Karl Hecker, lk 69).

read 12-16:

Minu tagasitulekul vallutasin ma ühtviisi Tu'muna, Rihihu, Jadaqqu, Hamrānu, Hagarān, Nabatu [ja] Li'tau, [minule] mitte truu-alamlikke aramea [hõime]. 208000 inimest, suuri [ja] väikeseid, mehi [ja] naisi, 7200 hobust [ja] muula, 11073 eeslit, 5230 kaamelit, 80100 härga [ja] 800600 lammast viisin ma raske saagina Ǎ̌šuri maale. Minu sõjakäigu jooksul sain ma Nabū-bēl-sumāte'lt, Hararatu linna valitsejalt, kulda, hõbedat, suuri mooruspuuvilju, eesleid, kaameleid, härgi ja lambaid kui ka tema kaalukaid andameid. Hirimmu linna elanikke, kangekaelseid [põikpäiseid] vastaseid, surusin maha [lõin maha] relvadega, mitte ühtegi järele jättes. Nende laibad riputasin ma postidele ning ümbritsesin nendega linna (TUAT 2005, kd 2, Karl Hecker).

Niisiis oli Sanherib deporteerinud Babülooniast Assüüriasse vähemalt 208000 inimest (Oded 1979: 21). Ja see vaid ühe sõjakäigu jooksul!

Juuda vallutust kirjeldab Sanherib samas raidkirjas järgnevalt: read 48-50:

Padi, nende kuninga, lasin ma Uršalimmust [Jeruusalemmast] välja tulla ja panin ta troonile nende üle valitsema ning kehtestasin andami [maksud] minu võimu jaoks. Juuda [kuninga] Hiskija ja tema 46 linna ja võimsat kindlust ning lugematul hulgal väikseid linnu nende ümbruses piirasin ma sisse (TUAT 2005, kd 2, Karl Hecker, lk 71; vt ka Oded 1979: 19).

Järgmises reas (rida 51) räägib Sanherib juba juutide deporteerimisest: 
200150 inimest, suuri ja väikeseid, mehi ja naisi, hobuseid, muulasid, kaameleid, härgi ja lambaid lugematul hulgal viisin ma nendest [linnadest] minema ja arvestasin need saagi hulka (TUAT 2005, kd 2, Karl Hecker, lk 71).

Selliseid näiteid võiks tuua Sanheribi, Sargon II, Assarhaddon või Aššurbanipali raidkirjadest veel tohutult, aga et käesoleva artikli maht on piiratud, piirdun osundatutega.

Sanheribi valitsemisajast võime tuua ühe näite, mida võib vaadelda küüditamispoliitika eriti negatiivse mõjuna - Juudas asuvas Shephelahis oli suurem osa elanikkonnast hävitatud või küüditatud Sanheribi 701. aasta retke ajal ja vahetult pärast seda. Enne retke seda 8. sajandil eKr oli Shephelahis kokku 276 linna ja elanikkond oli umbes 182000 inimest, kuid pärast Sanheribi retke 701. aastal ning 8 . ja 7 . sajandi vahetusel asetleidnud tapmisi ja deporteerimisi jäi sinna alles vaid 22500 inimest (Gitin 1997: 82). Seega leidis selles piirkonnas aset demograafiline katastroof ja selliseid piirkondi, mis jäid inimestest tühjaks, oli impeeriumis kümneid.

\section{Nasâhu-poliitika ohvrite statistika: kui palju oli küüditatuid kokku?}

Bustenay Oded tõi oma raamatus Lausdeporteerimised ja deporteeritud UusAssüüria impeeriumis (1979), ka statistilisi andmeid, kui palju rahvast mingi kuningas oli küüditanud. Samas võivad raidkirjadest ja muudest tekstidest meile teada olevad arvud olla ka tunduvalt suuremad, sest kõik raidkirjad pole arvatavasti veel leitud ega säilinud ning osa raidkirju on saanud tugevasti kannatada. B. Oded ise märgib, et ta pole oma uurimuses arvestanud üksikisikute ega väiksemate rühmade küüditamisi (Oded 1979: 19).

Kui palju küüditati inimesi kokku Uus-Assüüria ajal, st aastatel 883-612 a. eKr? Sellele küsimusele on väga raske vastata.

On teada, et Aššurnașirpal II (883-859, vt nt Mayer 1995: 267-274), UusAssüüria impeeriumi rajaja, edukas väejuht, suur vallutaja ja muidugi väga jõhker valitseja küüditas vähemalt 12900 meest ning viie juhtumi puhul pole küüditatute arvu mainitud. Tema poeg Salmanassar III (vt nt Mayer 1995: 274-289) paistis silma veelgi suurema deporteeritute arvuga - ta suutis küüditada vähemalt 167500 inimest, seejuures kolme juhtumi puhul pole küüditatute arvu mainitud. Tapetute hulk aga on lugematu, ulatudes nähtavasti samuti kümnetesse või koguni sadadesse tuhandetesse. Näitena toon vaid paar 
Salmanassar III küüditamis- ja vägivallategu. Raidkirjas Shalmaneser III A.0.102.2 on muu hulgas mainitud mitmete inimeste jõhker tapmine ja vangistamine. Esiteks mainib Salmanassar 700 sõjamehe tapmist mõõgaga (kusjuures mehed olid pärit erinevatest tema vastu astunud Süüria linnriikidest): "Mina raiusin maha/langetasin 700 nende sõjameest mõõgaga" (RIMA 3, Shalmaneser III A.0.102.2, col. II, lk 17, rida 3). Samas raidkirjas (Shalmaneser III A.0.102.2) hoopleb verejanuline despoot sellega, kui palju ta tappis Taia, Hazazu, Nulia ja Butāmu inimesi. Salmanassar III raidkirjast loeme:

Liikudes eemale merest, ma vallutasin Taia, Hazazu, Nulia ja Butāmu linnad, mis kuuluvad patinealastele. Ma tapsin maha 2800 [nende] sõjamehi [ja] viisin ära 14600 vangi (RIMA 3, Shalmaneser III A.0.102.2, col. II, lk 17, read 10-12).

Salmanassari raidkirjades (nagu enamikus Uus-Assüüria kuningate raidkirjades) on peamiselt juttu tapmisest, küüditamisest, veresaunadest, andami saamisest ning linnade hävitamisest ja põletamisest. Liikudest Tîl-Barsipi (ka Bursip, vt Bunnes 1997: 17-28) piirkonnast üle Eufrati, vallutas Salmanassar hulga väiksemaid kuningriike, hõime ja linnu, mh Sūrūnu, Paripa, Tīl-Bašer jne (RIMA 3, Shalmaneser III A.0.102.2, col. II, rida 16-18, lk 18):

Ma tapsin maha palju nende [inimesi ja] viisin minema nendelt saadud saagi. Ma tegin maatasa, hävitasin [ja] põletasin ära 200 linna nende ümbruskonnas.

Selliseid kirjeldusi esineb Salmanassari raidkirjades korduvalt ja üsnagi sageli. Näiteks sõjas Qarqari linnaga ning Damaskusega ja teiste Süüria linnadega mainib Salmanassar vähemalt 14000 sõjamehe (14 LIM ÉRIN.MEŠ) tapmist (RIMA 3, Shalmaneser III A.0.102.2, col. II, rida 97, lk 23, 24). Salmanassar III vallutused ulatusid mitmesse piirkonda, mitte ainult Süüriase ja Põhja-Mesopotaamiasse. Arvatavasti marssis tema sõjavägi ka Lõuna-Anatooliasse, kus elasid hetiidid, kelle võimu all olid mitmed väiksemad kuningriigid - kunagise võimsa Hetiidi impeeriumi (aastail 1650-1180 eKr) pärandi killud. Põhja-Süüriast ja Lõuna-Anatooliast ta "juuris välja 22000 inimest Hatti maalt ja viis neid Aššuri linna" (RIMA 3, Shalmaneser III A.0.102.3, read 98-99, lk 25). Salmanassar III võib mingil määral pidada ka muinasaja rekordimeheks just sõjaväe suuruse poolest. Kui muidugi uskuda tema sõnu, mida võib mõistagi mingil määral kahtluse alla seada, olevat ta kogunud koguni 120000 meest, et võidelda Damaskuse linna ja selle liitlastega (RIMA 3, Shalmaneser III A.0.102.6, col III, read 24-26, lk 39; vt ka Mayer 1995, 286: Für den Feldzug des 14. Jahres bot Salmanassar nach seinen Angaben 120000 Mann auf). Samas tun- 
dub 120000 sõjaväelast armees täiesti võimalik, sest kui arvestada et UusAssüüria impeeriumi elanikkonna arv umbes 9.-8. sajandil eKr polnud ilmselt oluliselt väiksem kui Rooma impeeriumi elanikkond, kus hiilgeajal 2. sajandi keskel pKr oli ligikaudu 60-65 miljonit inimest. Näiteks 395. aasta paiku pKr oli Rooma impeeriumis kokku kuni 500000 või isegi 600000 leegionäri (Grant 1998: 40). 3. sajandi alguseks keiser Septimius Severuse valitsemise ajal (193211) oli Rooma armees ligikaudu 400000 sõjameest (Grant 1998: 11).

Ka Salmanassar III järglane kuningas Šamši-Adad V (823-811, Mayer 1995: 289-292) deporteeris vähemalt 36200 inimest (Oded 1979: 20). Võimalik, et ta küüditas rohkemgi, aga teavet selle kohta pole. Ühes oma raidkirjas hoopleb Šamši-Adad V:

Nad sisenesid Uraši kaitse all olevasse linna, ja mina piirasin selle sisse, vallutasin selle, [ja] nende sõjameeste verega värvisin nende linnaväljaku [?] punaseks nagu punase villa. Ma tapsin maha 6000 nendest (RIMA 3, Šamšī-Adad V A.0.103.1, Col III, read 10-13, lk 185).

Järgmiste valitsejate Adad-nērārī III (Mayer 1995: 293-296), Salmanassar IV (Mayer 1995: 297-298), Aššur-dān III (Mayer 1995: 298-300) ja Aššur-nērārī V (Mayer 1995: 300) ajast pole küüditamistest eriti midagi teada. See oli ka aeg mil Assüüria käis alla ning valitsevaks jõuks Lähis-Idas sai Urartu kuningriik.

Kuid Tiglatpileser III (Mayer 1995: 301-315) taastas Assüüria võimsuse ja suurriigi. Ta tegi palju vallutuskäike, et viia Assüüria ülemvõim igale poole, kuhu aga jõudsid tema väed. Tema esimene suur sõjaline ettevõtmine, mis leidis aset ligikaudu 745. aastal oli John Anthony Brinkmani arvates keskendunud Põhja-ja Ida-Babülooniale. Põhjas ta jõudis välja Sippari ja Dur-Kurigalzu linnani, kuid ei saavutanud ülemvõimu Babüloonia tuumala ja Babüloni linna üle (Brinkman 1984: 40-41). J. A. Brinkman kirjutab Tiglatpileser III võitudest 745. aastal Idas: "Idas võitis ta mitmeid Arammena hõime, kaasa arvatud Adile, Dunanu, Hamranu ja Rabilu ning asustas vangistatud ümber vastrajatud linna nimega Kar-Ashur" (Brinkman 1984: 41). See oli vaid Tiglatpilseri tulevate sõjakäikude, deporteerimiste ja inimeste massilise hävitamise sissejuhatus. 732. aastal algas Babüloonias ülestõus. Kuningas Tiglatpileser asus sel hetkel Süürias. Kuid ta suutis kiiresti naasta ning järgmised kolm aastat sõdis ta Babüloonias, kuni surus mässu maha ja asus ise Babüloonia troonile, luues seega Assüüria-Babüloonia kaksikmonarhia (Brinkman 1984: 42-43).

Tiglatpileser III purustas lõpuks Urartu võimsuse ja just temaga algavad eriti ulatuslikud küüditamised. B. Odedi hinnangul küüditas Tiglatpileser III vähemalt 358543 inimest $+x+25055$ inimest. Seega kokku vähemalt 400000 inimest (Oded 1979: 20). See arv võib olla ka tunduvalt suurem, sest meie 
käsutuses pole kaugeltki kõiki tekste Tiglatpileser III ajast, vaid osa nendest, mis on leitud ja praeguseks ka tõlgitud. Samas on B. Odedi arvestus tehtud 30 aastat tagasi ja seega vananenud. Peaaegu igal aastal leitakse arhiivist mõni uus dokument, ja sadu arhiive koos sadade tuhandete Assüüria ametlike dokumentidega on alles välja kaevamata. Seega on loogiline oletada, et see arv võib kasvada isegi märgatavalt. Lisaks sellele on Tiglatpileser III ajast teada veel vähemalt 19 juhtumit, kus küüditatute arvu pole mainitud (Oded 1979: 20). Tiglatpileser III vallutusretked Süürias ja Palestiinas tähendasid Assüüria otsese kontrolli kehtestamist Levandi rannikul - Süüria ja Palestiina territooriumi liitmist Uus-Assüüria impeeriumiga ja nendest aladest provintside loomist (Gitin 1997: 77). Seymour Gitini sõnul oli Tiglatpileser III poliitika tulemuseks

pax Assyriaca, a period during which there was, for the most part, political stability and economic prosperity. Assyrian rule, which lasted through the second third of the 7th century, was reinforced by successive kings Shalmaneser V, Sargon II, Sennacherib, Esarhaddon and Ashurbanipal [pax Assyriaca - periood, mille vältel valitses enamasti poliitiline stabiilsus ja majanduslik õitseng. 7. sajandi teisel kolmandikul kehtinud Asüüria korda tugevdasid edukad kuningad: Salmanassar V, Sargon II, Sanherib, Esarhaddon ja Aššurbanipal] (Gitin 1997: 77).

Tiglatpileser III poeg Salmanassar V (Mayer 1995: 315-316), kes valitses vaid viis aastat, oli samuti suur vallutaja ja arvatavasti ka küüditaja, kuid meile on teada vaid üks juhtum, kus mainitakse küüditamist, ent küüditatute arv pole teada. 727. aastal eKr troonile asunud Salmanassar V kohta on meil väga vähe teada, kuid siiski teame, et ta küüditas kaldealasi Bit-Adinist (Brinkman 1984: 43).

Sargon II (722-704, Mayer 1995: 316-341), kelle trooninimi oli Šarru-kēnu ('õiglane/legitiimne kuningas') tuli võimule 722. aastal eKr. Tema ajal üritas Babüloonia mitu korda ülestõusu. Kaldealased ja assüürlased üritasid kordamööda saavutada kontrolli Babüloonia üle. Ka muud piirkonnad üritasid iseseisvuda, kuid Sargon suutis kõik mässukolded hävitada.

Kui uskuda allikaid, olevat Sargon II küüditanud koguni 217635 inimest + x inimest +21650 inimest ja lisaks on veel teada 24 juhtumit, mil küüditatute arvu pole mainitud (Oded 1979: 20). Absoluutseks rekordipüstitajaks Assüüria kuningate seas peetakse Sanheribi (704-680, Mayer 1995: 342-380), kes küüditas 408150 inimest $+\mathrm{x}$ inimest +61000 inimest, ja 17 juhtumi puhul pole küüditatute arv teada. Küüditamised jätkusid ka tema järeltulijate ajal. Unustada ei tohi siinjuures ka sadu tuhandeid tapetud babüloonlasi ja hulgaliselt 
teisi rahvaid. Tänaseks on teada Uus-Assüüria ajast vähemalt 157 juhtumit (ja see arv kasvab kogu aeg), kus on juttu küüditatutest, kuid vaid 43 korral on nimetatud deporteeritute arvu, 105 juhtumi puhul pole arvu teada (Oded 1979: 20).

Kogu Uus-Assüüria ajal st vaid 250 aasta jooksul oli B. Odedi arvestuse kohaselt (tuginedes teadaolevale 43 juhtumile) küüditatud vähemalt 1210928 inimest $+\mathrm{x}^{\mathbf{6}}+107705$ inimest ja 105 juhtumi puhul pole arvu teada. Kokku on see 1318633 + x inimest (Oded 1979: 19-21). See arv võis olla tunduvalt suurem, koguni mitu miljonit. Kui mõelda sadadele tuhandetele tapetud inimestele, kasvab represseeritute arv tõenäoliselt veelgi. Kuid samas ei tohi unustada asjaolu, et assüürlased võisid neid arve suurendada, nii et kõik arvutused on väga hüpoteetilised ja midagi ei saa väita täiesti kindlalt.

Kõnealusest 1318633 küüditatust kuulub enamik kolme kuninga valitsemisaega: Tiglatpileser III, Sargon II ja Sanherib küüditasid kokku vähemalt 1102033 + x inimest. Seega kolm kuningat küüditasid umbes 50-60 aasta jooksul rohkem kui miljon inimest. Muistse maailma ja Assüüria impeeriumi mõistes, mille hiilgeajal võis elanikke olla orienteeruvalt 30-50 miljonit, oli see tohutu arv.

Kui oletada, et vaid neljandikus juhtumitest on mainitud deporteeritute arvu, võib selle arvu korrutada vabalt kahega, isegi kolme või koguni neljaga. Siinjuures ei tohi unustada, et paljud raidkirjad ja tekstid pole veel avastatud või on mingil põhjusel hävinud. B. Oded teeb isegi kalkulatsioone ning viitab dr B. Eichorni statistilistele arvutustele, mille kohaselt kõikide küüditatute hulk Uus-Assüüria impeeriumis võis olla $4400000 \pm 900000$ inimest (vt Oded 1979: 20-21). See on muidugi vägagi hüpoteetiline arv ja teeb kokku kuni 5300000 inimest.

Kas see hüpoteetiline arv 5300000 võis tegelikkuses olla veelgi suurem? Seda ei tea. Ei saa välistada, et see võis olla ka tunduvalt väiksem, kui me seadme kahtluse alla assüürlaste esitatud arvud. Samas on nende arvestused enamasti üsna täpsed, fikseeritud ja tihtipeale on säilinud isegi deporteeritute nimekirjad, kus on lisaks isikute nimedele kirjas ka nende sotsiaalne staatus, päritolu jne.

Arvestades seda, et kogu aeg avastatakse kusagil muuseumis või arhiivis sadu ja tuhandeid tekste, mida keegi pole lugenud ja veel sadu tuhandeid on välja kaevamata, tundub küüditatute arv 5300000 üsna tõenäoline. Nagu mainisin, ei tohi aga unustada, et B. Odedi monograafia on 30 aastat vana. Assüüria kuningate raidkirjade ja muude dokumentide väljaandeid, mis ilmusid 1980. ja 1990. aastatel, B. Oded oma töös muidugi arvestada ei saanud. Kasvõi seda, et Münsteri Ülikooli arheoloogiaprofessori Reinhard Dittmanni ja teiste ar- 
heoloogide korraldatud väljakaevamistel 1980. aastatel Assüürias tuli näiteks Kar-Tukūltī-Ninūrtas välja uusi tekste ja raidkirju (vt lähemalt Dittmann jt 1988: 97-138; Dittmann 1997: 101-115; Pedersén 1989a: 153-167, 1989b: 135138). Selliseid väljakaevamisi tehti veelgi, kuid viimasel ajal pole need teatud põhjustel Iraagis kahjuks võimalikud. Olen veendunud, et küüditamisjuhtumite kohta peaks tegema uue arvestuse, kuid see tähendaks mitut aastat tööd. Praegu jääb küüditatute arvu küsimus minu meelest lahtiseks. Päris täpseid arve ei saa me arvatavasti kunagi teada. Siiski võib rääkida ligikaudsetest arvudest, ja need on hirmuäratavad.

Kas või põgusalt tuleb siinkohal puudutada ka terminoloogiat. Küüditatute kohta kasutati Assüürias oma termineid, ja neid oli koguni mitu. Siinkohal mainiksin ära järgmised - sumerogramm lúERIM.MEŠ ja akkadi keeles kui $s \bar{a} b \bar{u}(s a b u)$, sumerogramm ÙKU.MEŠ ja akkadi keeles kui nišū, sumerogramm ZI.MEŠ ja akkadi keeles kui napšāti (Oded 1979: 22). Kõik need mõisted esinevad Assüüria kuningate annaalides ja muudest tekstides. Näiteks väljend șeher rabi zikar u šinniš esineb Uus-Assüüria kuningate raidkirjades tihti (Sargon II, Sanehrib), seda võib tõlkida kui inimesi, suuri ja väikeseid, meessoost ja naissoost (Oded 1979: 23).

Küüditatuid on mh kujutatud ka Assüüria kuningate bareljeefidel. Samuti massimõrvu.

Kust ja kuhu siis inimesi küüditati? Peamiselt olid haaratud Babüloonia, Egiptus, Süüria, Eelam, Meedia, Foiniikia, Urartu, Lõuna- ja Ida-Anatoolia ja ka teised alad. Kaugeltki mitte kõikides juhtumites pole teada, kuhu küüditati ja kust on küüditatud. Vaid 74 juhtumi puhul teame, kuhu küüditatuid viidi (Oded 1979: 27). See teeb parimal juhul umbes 50\% kõikidest juhtumitest, mis on meil hetkel teada. Aga ikkagi - kust ja kuhu siis küüditati? Näiteks Sargon II viis Samaaria elanikke Assüüriasse ja Meediasse ning tõi nende asemele Samaariasse inimesi Mesopotaamiast (Oded 1979: 27). Kuigi näiteid on tohutult, piirdugem veel paariga. Kuningas Assarhaddon (680-669 eKr), kes täielikult hävitas Foiniikias asuva suure ja mõjuvõimsa Sidoni linna, küüditas hulgaliselt Sidoni ja selle ümbruse elanikke Assüüriasse ning ehitas Sidoni lähedusse Kar-Asarhaddoni linna, kuhu tõi inimesi hoopis idast. Tema poeg kuningas Aššurbanipal viis inimesi Egiptusest Assüüriasse ja tõi Egiptusesse elamiite idast Lõuna-Iraani aladel asunud Eelamist (Oded 1979: 29).

\section{Kokkuvõte}

Nagu nägime, käitusid Assüüria valitsejad rahvaste ja hõimude alistamisel ning mässude mahasurumisel äärmiselt jõhkralt ja järjekindlalt. Tapetute ja küüditate arv võis ulatuda miljonitesse. Ainuüksi deporteerituid oli tagasi- 
hoidlikumate hinnangute kohaselt ligi 1,5-2 miljonit, teiste hinnangute põhjal koguni 4-6 miljonit. See on maailma ajaloos esimene selline nähtus, mida hiljem harrastasid Uus-Babüloonia kuningad Nebukadnetsar II, Nabuna'id, seejärel pärslased jne. Kuid arvatavasti jäid nad assüürlastele siiski alla.

Üleüldse nägi Uus-Babüloonia kuningriik (626-539) ennast Assüüria impeeriumi poliitika jätkajana, sama ideoloogilise ja geopoliitilise suuna esindajana. Seetõttu küüditasid Uus-Babüloonia kuningad üsnagi tihti vallutatud rahvaid või mässulisi hõime. Näiteks, 586 . aastal $\mathrm{eKr}$ vallutas Babüloonia kuningas Nebukadnetsar II Jeruusalemma, kuningas Zedekiah põgenes linnast, kuid langes peagi Jeeriko läheduses vangi. Nebukadnetseri käsul torgati Zedekiah (kreekapäraselt Zedekias) silmad välja ja ta viidi Babüloni, kus ta suri vangina. 17. augustil 586. aastal saabus Jeruusalemma tähtis Babüloonia ametiisik Nabu-zer-iddin kuninga käsuga hävitada Jeruusalemm. Babüloonlased põletasid Jeerusalemmas maha kõik ehitised, templi jne. Kõik ellujäänud (kokku 832 inimest) viidi vangidena Babülooniasse. Selliseid näiteid on veelgi. Nagu näeme, kasutasid assüürlaste järeltulijatest, Uus-Babüloogia kuningad assüürlaste juurutatud nasâhu-poliitikat vägagi aktiivselt (Beljavski 2001, 96).

Antud teemal võiks kirjutada veel pikalt. Kõnelda võiks kasvõi sellest, millistel põhjustel olid küüditatud ühed või teised rahvad ja kuhu neid viidi. Ainus, millele tahan veel tähelepanu osutada, on asjaolu, et Assüüria kuningate teostatud jõhker küüditamine ja massimõrvamine oli ametlik ja populaarne riiklik poliitika, millel olid majanduslikud, poliitilised ja ideoloogilised eesmärgid. Assüüria kui üks vanimaid varatotalitaarseid impeeriume maailma ajaloos paistis esimesena silma sellise pideva julma poliitikaga vallutatud rahvaste ja riikide suhtes (vt varatotalitarismist Egiptuses Amenhotep IV ajal Kulmar 2009: 111-122).

Vallutatud rahvaid hirmutati ja terroriseeriti mitmel eesmärgil:

Esiteks selleks, et vallutatud rahvad ja hõimud ei alustaks taas ülestõusu ja oleksid võimalikult truud impeeriumile, maksaksid makse jne.

Teiseks hirmutas ülikarm poliitika ka naaberriike ja -rahvaid, ning neil kadus soov tegutseda Assüüria vastu. Juhul kui mingi piirkond või hõim alustas ülestõusu, hävitasid assüürlased mässajad tavaliselt täielikult ja tihtipeale ka osa tsiviilelanikkonnast, et jääks võimalikult vähe inimesi, kes võiksid tulevikus mässata. See osa elanikkonnast, mida ei suudetud või ei soovitud hävitada, viidi kodumaalt ära orjadeks, et neil poleks enam võimalik tagasi tulla ja mässata ning et nad sõltuksid veelgi rohkem Assüüria kuningatest. Küüditatute asemele toodi teisi rahvaid ja ka põlisassüürlasi. St leidis aset ka paljude rahvaste assimileerimine. Assüüria impeeriumi niigi kirju etniline pilt muutus veelgi kirjumaks. 
Kolmandaks olid majanduslikud põhjused. Vallutatud alad rüüstati tavaliselt täielikult, saadud sõjasaagi arvelt maksid Assüüria kuningad armeele palka ja täitsid riigikassat, ehitasid silmapaistvaid losse ja templeid Niineves, Aššuris, Kalahis ja Dur-Šarrukinis. Samuti tõid küüditatud rahvad Assüüriasse palju uusi oskusi ning õppisid ka ise assüürlastelt palju. See stimuleeris mõnes mõttes majanduse arengut, eriti kaubandust ja tootmist. Kuid tehnoloogia levitamisega kaasnesid halvad kõrvalnähud vallutatud rahvastele, kes said tugevasti kannatada, aga eelkõige Assüüria riigile ja rahvale. Paljud piirkonnad jäid inimtühjaks, majandus käis seal alla, põllud jäid harimata ja niisutussüsteemide korrashoidmiseks ei jätkunud inimesi.

Lõppkokkuvõttes kasvas teiste rahvaste ja riikide viha Assüüria vastu, moodustusid üha tugevamad liidud, kuhu tavaliselt kuulusid Babüloonia, Eelam, Urartu, Meedia, araablased, vahel ka Egiptus, Süüria, Foiniikia ja Palestiina linnriigid. Assüüria valitsejad olid sunnitud nendega kogu aeg sõdima, ning kuni Assüürial jätkus jõudu, suudeti vastu pidada ja mässud maha suruda. See aga laastas riiki ja selle majandust. Assüüria armee oli muutunud nüüd multinatsionaalseks ja polnud enam huvitatud riigi püsimisest, assüürlaste endi osakaal riigis ja armees kahanes tohutult. Armee huvitus vaid rüüstamisest ja saagist. Põlisassüüria rahvas assimileerus, sulandus teiste rahvastega ja oli väljasuremise äärel. Jõhker nasâhu-poliitika ja muud faktorid, Assüüria sisemine ebastabiilsus ja majanduslangus viisid impeeriumi traagilise hävinguni. Mitme sajandi jooksul loodud ning sõjaväe ja majanduslike meetmetega ülal hoitud Pax Assyriaca lakkas olemast.

\section{Kommentaarid}

1 Käesolev artikkel valmis ETF grantide 6625 ja 6685 toetusel.

2 Salmanassar I vallutuste kohta vt Harrak 1987: 132-205; Jakob 2003: 9.; HeinholdKrahmer 1988: 79-104; vt ka RIMA 1: A.0.77.1, read 58-87, lk 183; Weidner 1969: 519-531.

${ }^{3}$ Babüloonia vallutamise kohta vt Cancik-Kirschbaum 2003: 51; Lambert 2004: 199: Tukulti-Ninurta has used his conquest of Babylon after the defeat of Kaštliyaš not only to take away the statue of the god Marduk, but also to bring back learned cuneiform tablets among booty [Tukulti-Ninurta kasutas Babüloonia vallutamist pärast Kaštiliaši lüüasaamist mitte üksnes selleks, et viia minema jumal Marduki kuju, vaid ka selleks et tuua muu saagi hulgas tagasi kiilkirjatahvlid]; Nemirovski 2007: 1617: Как известно из надписей Тукульти-Нинурты, в некоторый момент своего правления он «пошел на битву с Каштилиашем, царём Кардуниаша», победил и пленил его, увел в Ашшур и «стал господином всего Шумера и Аккада». Одна из надписей Тукульти-Нинурты вслед за этим сообщает: «я привел под одну власть страны (перечисляюттся страны Приефратья и Загроса, составлявшие окраинные 
владения Касситской Вавилонии - А.Н.). Они регулярно приносили дань их земли и плоды своих гор мне». Только после этого царь приступил к планированию и строительству своей новой столицы, Кар-Тукульти-Нинурты. [On teada, et mingil valitsemishetkel "astus ta lahingusse Karduniaši valitseja Kaštiliašiga", võitis ja vangistas ta, viis Assüüriasse ja "sai kogu Sumeri ja Akkadi valitsejaks". Üks Tukūltī-Ninūrta raidkirjadest teatas selle järel: "ma võtsin ühe valitsuse alla riigid (loetletakse kassiidi-aegse Babüloonia äärealade riike $-A$. $N$.). Igal aastal saan ma regulaarselt andamit nendest maadest ja nende mägede vilju." Ent pärast seda asus valitseja kavandama ja ehitama oma uut pealinna Kār-Tukūltī-Ninūrtat.]

4 Bel - Marduk. Bel ehk bēlu(m) tähendas akkadi keeles 'isandat'.

5 Akìtu - babüloonlaste uusaastapidustused, mida korraldati Babüloni linnas ja mis kestsid mitu päeva.

${ }^{6}$ Märk "x" tähistab antud juhul seda, et pole täpselt teada kui palju inimesi on küüditatud.

\section{Kirjandus}

Beljavski 2001 = Белявский, Виталий А. 2001. Тайны Вавилона. Москва: Издательство Вече.

Brinkman, John Anthony 1984. Prelude to Empire: Babylonian society and politics, 747-626 B.C. Occasional publications of the Babylonian fund 7. Philadelphia.

Cancik-Kirschbaum, Eva 2003. Die Assyrer. Geschichte, Gesellschaft, Kultur. Beck C. H.

Dieter, Horst. \& Günther, Rigobert 1990. Römische Geschichte 3. väljalase. Berlin: VEB Deutscher Verlag der Wissenschaften.

Dittmann, Reinhard \& Eickhoff, Tilman \& Schmitt, Rainer \& Stengele, Roland \& Thürwächter, Sabine 1988. Untersuchungen in Kār-Tukultī-Ninurta (Tulūl al-'Aqar) 1986. Mitteilungen der Deutschen Orient-Gesellschaft 120, lk 97-138.

Dittmann, Reinhard 1997. Die inneren und äusseren Grennzen der mittelassyrischen Residenzstadt Kar-Tukulti-Ninurta/Nord-Iraq. Grenzen und Stadt, Veröffentlichung der interdisziplinären Arbeitsgruppe-Stadtkulturforschung. I.A.S., Hrsg. von M.Jansen und P. Johanek, Aachen, 1997, Band 2, 2. Symposium im Münster vom 24.-26. Juni 1994, lk 101-115.

Durant 1995 = Дюрант, Вилл 1995. Цезарь и Христос. История цивилизации. Москва: Крон-Пресс.

FAOS 7 = Gelb, Ignace J. \& Kienast, Burhard 1990. Die altakkadischen Königsinschriften des Dritten Jahrtausends v.Chr. Stuttgart: Franz Steiner Verlag.

Gitin, Seymor 1997. The Neo-Assyrian Empire and its Western Perephery: The Levant, with a Focus on Philistine Ekron. Parpola, Simo \& Whiting, Robert McCray (toim). Assyria, 1995: Proceedings of the 10th Anniversary Symposium of the Neo-Assyrian Text Corpus Project, Helsinki, September 7-11, Helsinki: Neo-Assyrian Text Corpus Project, lk 77-103 
Grant 1998 = Грант, Майкл. Крушение римской империи. Москва: Терра.

Grayson, Albert Kirk 1975. Assyrian and Babylonian Chronicles. Texts from Cuneiform Sources V, Chronicle 16. Locust Valley, New York: J. J. Augustin Publisher.

Harrak, Amir 1987. Assyria und Hanigalbat: A Historical Reconstruction of Bilateral Relations from the Middle of the Fourteenth to the End of the Twelfth Centuries B.C., Texte und Studien zur Orientalistik 4. Hildesheim \& Zürich \& New York: Georg Olms Verlag.

Heinhold-Krahmer, Susanne 1988. Zur Salmanassars I. Eroberungen im Hurritergebiet. Archiev für Orientfosrchung 35, lk 79-104.

IDV 1983 = Дьяконов, Игорь (toim). История древнего Востока. Часть первая. Месопотамия. Москва: Наука.

Jaritz, Kurt 1964. Babylon und seine Welt. Bern \& München: Francke Verlag.

Klengel, Horst 1961. Tukulti-Ninurta I. König von Assyrien. Das Altertum 7, lk 67-77.

Kulmar, Tarmo 2009. Vaarao Amenhotep IV (Ehnatoni) riigivalitsemisviisi võimalikust eripärast. Mäetagused 42, lk 111-122.

Llop Raduá, Jaume 2003. Die persönlichen Gründe Tiglat-Pilesers I. Babylonien anzugreifen. Orientalia 72, lk 204-210.

Lambert, Wilfred G. 2004. The Enigma of Tukulti-Ninurta I. Frame, Grant \& Wilding, Linda (toim). From the Upper Sea to the Lower Sea. Studies on the History of Assyria and Babylonia in Honor of A. K. Grayson. Nederlands Instituut Voor Het Nabije Oosten, lk 197-202.

Mayer, Walter 1995. Politik und Kriegkunst der Assyrer. Abhandlungen zur Literatur Alt-Syrien-Palästinas und Mesopotamiens. Band 9. Münster: Ugarit.

Nemirovski 2007 = Немировский, Александр А. Письмо Хаттусилиса III КадашманЭллилю II (KBO I 10) и вопросы ближневосточной хронологии. Вестник древней истории $3,1 \mathrm{k} 3-27$.

Oates, Joan 1979. Babylon. London: Thames and Hudson.

Oded, Bustenay 1979. Mass Deportations and deportees in The Neo-Assyrian Empire. Wiesbaden: Dr. Ludwig Reichert Verlag.

Olmstead, A.T. 1917. Tiglath-Pileser I and his wars. Journal of the American Oriental Society 37 , lk 169-185.

Pedersén, Olof 1989a. Die Assur-Texte in ihren archäologischen Zusammenhängen. Mitteilungen der Deutschen Orient-Gesellschaft 121, Berlin, lk 153-167.

Pedersén, Olof 1989b. Remains of a Possible Old Assyrian Archive ('O 2') in the Schotterhofbau. Mitteilungen der Deutschen Orient-Gesellschaft 121, Berlin, lk 135-138.

Porter, Barbara Nevling 2003. Trees, Kings, and Politics. Studies in Assyrian Iconography. OBO 197. Göttingen: Academic Press Fribourg Vandenhoeck \& Ruprecht.

RIMA 1: Grayson A. Kirk 2002. Assyrian Rulers of the Third and Second Millennia BC (to 1115 BC), The Royal Inscriptions of Mesopotamia, Assyrian Periods. 1. Toronto \& Buffalo \& London: University of Toronto Press 1987, reprinted 2002. 
RIME 2 = Frayne, Douglas F. 1993. Sargonic and Gutian Periods (2334-2113 BC). The Royal Inscriptions of Mesopotamia, Early Periods. 2. Toronto \& Buffalo \& London: University of Toronto Press.

RIMA 3 = Grayson, A. Kirk 1996. Assyrian Rulers of the Early First Millennium BC 2, (858-745 BC). Royal Inscriptions of Mesopotamia. Assyrian Periods 3. Toronto: University of Toronto Press.

Sazonov, Vladimir 2006. Arad-Ahhešu kiri Aššurbanipalile. Tuna 1, lk 80-87.

Sazonov, Vladimir 2008. Sargoniidide uus religioonipoliitika templite suhtes ning selle poliitika paradigmaatilisus. Verbum Habet Sakala nova series 1, lk 14-24 (http:// korpsakala.ee/img/VHS_2007_NS.pdf - 15. märts 2010).

Stadnikov, Sergei 1998. Vana-Egiptuse kultuurilugu. Tallinn: Kodutrükk.

Tadmor, Hayim 1994. The Inscriptions of Tiglath-pileser III King of Assyria: critical edition, with illustrations, translations and commentary. Jerusalem: Israel Acadamy of Sciences and Humanities.

TUAT 2005 = Jankowski, Berndt \& Wilhelm, Gernot (toim). Texte aus der Umwelt des Alten Testaments. Neue Folge, Band 2. Staatsvertäge, Herrscherinschriften und andere Dokumente zur politischen Geschichte. Gütersloh: Güterslohwer Vergshaus.

Weidner, Ernst 1969. Assyrien und Hanilgalbat. Mission de Ras Shamra XVII. Ugaritica VI, lk 519-531.

\section{Summary}

\section{Deportation as an Ancient Tradition in the Neo- Assyrian Empire during 9th-7th Centuries BC}

\section{Vladimir Sazonov}

Key words: Assyria, Babylon, deportation, early totalitarian society, nasâhu-politics, Tiglath-pileser III, Sargon II, Sennacherib

The current paper focuses on the complicated issue of a very widespread political method, deportation, in the Neo-Assyrian Empire since the middle of the 9th century up until 612 BC. Naturally, the idea is much older - some Sumerian and Old Akkadian kings in Mesopotamia (e.g. Rimush of Akkad, etc.) had already deported certain groups of peoples of conquered territories in the 3rd millennium BC, though, this was not a common political practice at the time. Later, in the 1st millennium BC, Assyrians began to practice deportation as a regular political means in order to establish their hegemony over the Near East space, the "oikoumene" in the understanding of ancient Mesopotamians. Thus, all or nearly all of the Neo-Assyrian kings had actively incorporated this policy in the political system of their state, and frequently deported the conquered peoples of the Near East for intimidating purposes and to suppress any 
separatist action, as, e.g., revolts. Such politics had indeed a certain effect on the imperial stability, keeping the empire from collapse, yet also entailed a very negative concurrent impact on the Assyrian population, economy of the state and demography all this contributed to the downfall and degeneration of the Neo-Assyrian Empire and the imperial system, ending in a complete destruction of the Assyrian capital cities Nineveh and Ashur - by Babylonians, Scythians and Medes who conquered the weakened Assyria, demolished its power and killed the majority of native Assyrians at the end of the 7th century BC. 